\title{
Gully network expansion and spatial and temporal dynamics of catchment geomorphic characteristics and gully topographical thresholds in the semi-arid Ethiopian Rift Valley
}

\author{
Shiro Mukai ${ }^{1}$, Paolo Billi ${ }^{2}$, Nigussie Haregeweyn ${ }^{3}$, Mesenbet Yibeltal ${ }^{4}$, and Tilahun \\ Hordofa $^{5}$ \\ ${ }^{1}$ My home \\ ${ }^{2}$ University of Ferrara \\ ${ }^{3}$ Tottori University \\ ${ }^{4}$ Bahir Dar University \\ ${ }^{5}$ Ethiopian Institute of Agricultural Research
}

April 28, 2020

\begin{abstract}
To analyse the driving forces of gully erosion using a present dataset of geomorphic parameters and land use/cover involves limitations because past datasets at the time of gully incision may best explain the gully formation and evolution at that time. The recent development of photogrammetric techniques enabled to estimate temporal gully volume changes. This study conducted in semi-arid Ethiopian Rift Valley used field measurements and gully volume-length relation to analyse spatial and temporal dynamics of catchment geomorphology and topographical threshold of gully heads to explain the difference in the gully volumes and area-specific gully volumes between two study sub-areas. The topographic thresholds of the gully heads, expressed by the slope $(=\mathrm{s})$ and drainage area $(=\mathrm{a})$, (i) formed in each catchment and (ii) that had the same land use/cover items (forest, grassland, and farmland) in all the catchments of each sub-area were approximated by power functions ( $\mathrm{s}=\mathrm{ka-b}$ ). Analysis of covariance found that these threshold lines had clear spatial and temporal patterns: the threshold lines maintained almost the same exponent b specific to each sub-area while the threshold coefficient k significantly decreased in the order of forest, grassland, and farmland. The spatial variability and its temporal changes in relief aspect of the catchment morphology can responsible for the difference in the area-specific volumes of gullies between the sub-areas, while the continuous reduction in vegetation cover over time can be the main driving force of the similar scale and changing patterns of the gully volumes between the sub-areas.
\end{abstract}

\begin{abstract}
To analyse the driving forces of gully erosion using a present dataset of geomorphic parameters and land use/cover involves limitations because past datasets at the time of gully incision may best explain the gully formation and evolution at that time. The recent development of photogrammetric techniques enabled to estimate temporal gully volume changes. This study conducted in semi-arid Ethiopian Rift Valley used field measurements and gully volume-length relation to analyse spatial and temporal dynamics of catchment geomorphology and topographical threshold of gully heads to explain the difference in the gully volumes and area-specific gully volumes between two study sub-areas. The topographic thresholds of the gully heads, expressed by the slope $(=s)$ and drainage area $(=a)$, (i) formed in each catchment and (ii) that had the same land use/cover items (forest, grassland, and farmland) in all the catchments of each sub-area were approximated by power functions $\left(s=k a^{-b}\right)$. Analysis of covariance found that these threshold lines had clear spatial and temporal patterns: the threshold lines maintained almost the same exponent $b$ specific to
\end{abstract}


each sub-area while the threshold coefficient $k$ significantly decreased in the order of forest, grassland, and farmland. The spatial variability and its temporal changes in relief aspect of the catchment morphology can responsible for the difference in the area-specific volumes of gullies between the sub-areas, while the continuous reduction in vegetation cover over time can be the main driving force of the similar scale and changing patterns of the gully volumes between the sub-areas.

KEYWORDS: gully evolution, area-specific gully volume, gully volume-length relation, catchment geomorphology, topographic threshold

\section{INTRODUCTION}

In East and South African countries, large-scale gullies can be seen almost everywhere (Katsurada et al., 2007; Ndomba, Mtalo, \& Killingtveit, 2009; Boardman, 2014). In semi-arid Ethiopian highlands (Tigray), the area-specific gully erosion rates (gully erosion rate per unit area) since gully incision to 2001 were $6.2-17.6$ $\mathrm{Mg} \mathrm{ha}^{-1} \mathrm{y}^{-1}$ (Nyssen et al., 2006; Frankl et al., 2013a). In sub-humid Ethiopian highlands (Amhara), the area-specific gully erosion rates were $8.7-155 \mathrm{Mg} \mathrm{ha}^{-1} \mathrm{y}^{-1}$ (Tebebu et al., 2010; Zegeye et al., 2016; Yibeltal et al., 2019). In semi-arid Ethiopian Rift Valley, a lowland part of Ethiopia, the area-specific gully erosion rate was 16.2 $\mathrm{Mg} \mathrm{ha}^{-1} \mathrm{y}^{-1}$ (Mukai, 2017). Most gully volumes showed an exponential increase since gully incision in Ethiopia except the ones in the areas where gully rehabilitation or soil and water conservation programmes at watershed scale were implemented (Nyssen et al., 2006; Frankl et al., 2013a). The contribution of gullying to total soil loss from the area ranges from $28 \%$ in semi-arid highlands (Nyssen et al., 2008) to 64 to more than $90 \%$ in sub-humid highlands (Tebebu et al., 2010; Zegeye et al., 2016) of Ethiopia.

Gully formation and its evolution are regulated by various factors, such as several geomorphic properties of catchments, slope gradient, land use, vegetation, and rainfall characteristics (Poesen et al., 2003; Valentin, Poesen, \& Li, 2005). Land use and vegetation cover are a major controlling factor of gully initiation (Parkner et al., 2006; Gómez Gutiérrez, Schnabel, \& Lavado, 2009) and its evolution (Martinez-Casasnovas, Ramos, \& Garcia-Hernandez, 2009). Many studies that used a statistical approach concluded that the present land use/cover was not a decisive factor of gully erosion (Muňoz-Robles et al., 2010; Kompani-Zare et al., 2011; Frankl et al., 2013b; Mukai, 2017). Using sequential historical aerial photographs and photogrammetric technique, Gómez Gutiérrez, Schnabel, \& Lavado (2009) determined temporal changes in gullied areas over $\sim 60$ years in southwest Spain, which were explained by temporal changes in land use and vegetation cover in respective years determined by the combination of aerophoto-interpretation and field observation. Martinez-Casasnovas, Ramos, \& Garcia-Hernandez (2009) used similar techniques to explain the impact of land use/cover changes on gully sidewall erosion in northeast Spain. Mukai (2017) found that the gully erosion rates of the study gully networks during the respective study periods in the present and the past had significantly strong correlations with the rates of area changes in land use/cover items during the respective study periods. These pieces of evidence show the importance of an analysis that analysed the relationship between gully erosion and past land use/cover when gullies were initiated.

It is well known that gully initiation and gully head positions are related to some critical conditions, e.g., the topographic threshold, a combination of the slope at the gully head $(s)$ and upslope drainage area $(a)$, which is expressed in equation (1):

$s=k a^{-b}(1)$,

where the threshold coefficient $k$, is a constant that varies with local climate, soils, and vegetation covers, and the exponent $b$, is a constant which is related with the dominant process of the flow conditions in a gully channel, e.g., surface or sub-surface flows (Torri \& Poesen, 2014). Land use that reduces vegetation cover, such as an increase in cultivated area and transformation of forest to grassland, tends to reduce the topographic threshold levels and increase the risk of gully erosion on sites (Parkner et al., 2006; Gómez Gutiérrez, Schnabel, \& Lavado, 2009). Using sequential historical aerial photographs and digital elevation models (DEM), Parkner et al. (2006) determined the $s$-a relationships (topographic threshold) of the gully heads formed in the 24 active gullies and gully complexes in New Zealand back to the time when gully heads were incised. Land use and vegetation cover in individual years was determined by mainly aerophoto- 
interpretation. They found the $s$ - $a$ relationships were related to land use/cover at the time of gully incision. When the land use of a catchment was an indigenous forest, the topographical threshold value was very high. As the land use changed to pasture, to invaded scrub, and to reforestation, the value decreased rapidly, then slowly increased, and finally returned to a similar level to that under indigenous forest. Gómez Gutiérrez, Schnabel, \& Lavadzo (2009) took a similar approach and proposed a topographical threshold evolution model based on land-use changes in respective study years in southwest Spain. Thus, some studies have indicated that land use and vegetation cover in the catchments at the time of gully incision explained the spatial variability in gully topographical threshold values well. However, the studies that quantitatively assessed the relationships between land use/cover and a difference in topographical threshold values were rare.

Some gully morphological characteristics have recently been used to determine temporal gully volume changes. Several studies have explored the relationship between the gully volume $(V)$ and length $(L)$ using a power equation $V=\mathrm{a}^{\mathrm{b}}$ ( $V-L$ relation; e.g., Frankl et al., 2013b). Li et al. (2017) proposed a relation between the gully volume $(V)$ and gully area $(A g)$ using a power equation $V=a A g$ b. These models have advantages that the length and area of a gully can be easily determined from aerial photographs and high-resolution satellite images. These photogrammetric techniques were utilised to assess long-term changes in gully volumes (Frankl et al., 2013a; Mukai, 2017).

Concerning other controlling factors of gully erosion that show temporal variation, such as catchment geomorphic characteristics, many studies analysed the present parameters and indices (Singh, Sarangi, \& Sharma, 2008; Chandrashekar et al., 2015). Using a statistical approach, Tamene et al. (2006) and Haregeweyn et al. (2008) quantitatively explained the spatial variability of sediment yield and area-specific sediment yield by various controlling factors that included the present catchment geomorphic parameters in semi-arid Ethiopian highlands. However, the relationships between the temporal changes in the catchment geomorphic parameters and gully evolution (e.g., gully volume changes) have rarely been quantitatively analysed except the $V-L$ relation. Mukai (2017) quantitatively analysed the relationship between the temporal changes in the catchment geomorphic parameters and gully erosion; however, how that relationship had implications to the spatial variability of gully evolution in agroecology had not been analysed.

The objectives of this study carried out in semi-arid Ethiopian Rift Valley were three-fold. It was, first, to analyse spatial and temporal dynamics in catchment geomorphology quantitatively and explain the difference in gully evolution (i.e., changes in the gully volumes and area-specific gully volumes) specific to each of the two study sub-areas. Secondly, it is to quantitatively assess the relationships between temporal changes in land use/cover items and topographical threshold of gully heads in each sub-area, and to explain the difference in gully evolution specific to the sub-area; and (iii) to confirm that the combination of the $V-L$ relation and field measurements is feasible to assess the interactions between environmental changes and gully erosion/gully head positions.

\section{MATERIALS AND METHODS}

\subsection{Study area}

The details of the study area and field measurement are given in Mukai (2017) and their summary is outlined below.

The Tebo and Geldia catchments $\left(\sim 285 \mathrm{~km}^{2}\right.$; Figure 1) geographically contain (i) northern Tebba Gersa mountainous area that is a part of the Ethiopian highlands $(2200 \mathrm{~m}$ asl), (ii) the southern lowland of the Rift Valley floor ( $\sim 1500 \mathrm{~m}$ asl), and (iii) intermediate transitional area. The catchments and permanent gullies in the Tebo and Geldia catchments can be divided into two geographical sub-categories: the Rift margin sub-area (gullies) and the Valley floor sub-area (gullies; Billi \& Dramis, 2003). From the Rift margin sub-area, five catchments (Boruamba, Telilo, Adare, Gebruamba, and Koka), which originate from either the southern margin of the Tebba Gersa mountainous area or the steep slope on the fault scarp, were selected as study catchments (Figure 2). From the Valley floor sub-area, seven catchments (Hadaware, Merko, Goro, Abharo, Kawa adami, Aware, and Odalega), which originate from the vicinity of the Merko hillside (1500-1600 $\mathrm{m}$ asl), were selected as study catchments. 


\subsection{Field measurements}

Aerial photographs of the study area taken in 1957, 1972, and 2005 (1:50,000 scale) were used for the analysis. Geometric rectification and photogrammetric restitutions were performed using ground control points, and a DEM (10 m pixel size) for the 2005 orthophotograph with positional accuracy in terms of root-meansquare errors $\left(\mathrm{RMSE}_{\mathrm{xyz}}\right)$ of $2.4,3.7$, and $3.5 \mathrm{~m}$ was constructed. The geometric rectification performed by co-registration with the 2005 orthophotograph resulted in root-mean-square errors $\left(\mathrm{RMSE}_{\mathrm{xy}}\right)$ of 3.7-3.8 and $3.2-3.4 \mathrm{~m}$ for the 1957 and 1972 aerial photographs. In the field surveys conducted in 2005, the dimensions of gully cross-sections and the length of each gully section were measured for 127 gully points selected from the Rift margin catchments and 139 gully points selected from the Valley floor catchments.

After the field measurement in the 12 study catchments, relationships between the volume of a gully network $\left(V, 10^{3} \mathrm{~m}^{3}\right)$ and the length of the gully network $(L, \mathrm{~km})\left(\right.$ a $V$ - $L$ relation) was calculated as $V=0.870 L^{1.406}$ $\left(n=12, r^{2}=0.963\right)$. This power function was used to estimate the volumes of gully networks in 1957 and 1972. The area-specific volume of a gully network $\left(V_{a}, 10^{3} \mathrm{~m}^{3} \mathrm{~km}^{-2}\right)$ was estimated by the equation of $V_{a}=$ $V / A$ where $A\left(\mathrm{~km}^{2}\right)$ is the catchment area of the gully network. A gully erosion rate in a mass unit for each of the catchments $\left(E M ; 10^{3} \mathrm{Mg} \mathrm{y}^{-1}\right)$ was estimated by the equation of $E M=(V$ end $B D$ end $-V$ start $B D$ start $) /(Y$ end $-Y$ start $)$ where $B D\left(\mathrm{Mg} \mathrm{m}^{-3}\right)$ is the approximation of soil bulk density and $Y$ is year (1957, 1972, and 2005); the subscriptsstart and end represent the starting and ending years of estimation. Similarly, an area-specific gully erosion rate in a mass unit $\left(A E M ; \mathrm{Mg} \mathrm{ha}^{-1} \mathrm{y}^{-1}\right)$ was estimated by the equation of $A E M=(V$ end $B D$ end $/ A$ end $-V$ start $B D$ start $/ A$ start $) /(Y$ end $-Y$ start $)$. Information on land use/cover in the 12 catchments was collected from the 2005 field survey, interviews, and aerophoto-interpretation.

Some geomorphic indices were used to analyse the temporal changes in areal and relief aspects of the study catchments in 1957, 1972, and 2005: (i) compactness coefficient (CC ; Gravelius, 1914); where Pe (km) is catchment perimeter. (ii) Form factor ( $F F$; Horton, 1932); $F F=A / H L^{2} \pi$ where $H L(\mathrm{~km})$ is maximum catchment length. (iii) Relief ratio $(R R$; Schumm, 1956); $R R=H D C / H L$ where $H D C(\mathrm{~km})$ is a height difference between the outlet $\left(H_{\min }\right)$ and the highest point in the catchment $\left(H_{\max }\right)$. The absolute elevation difference within the catchment $(H D C)$ represents the potential energy available for soil erosion (Verstraeten, \& Poesen, 2001). A high relief ratio corresponds to a more pronounced topography and thus to a higher erosion risk (Verstraeten, \& Poesen, 2001). (iv) Lemniscate ratio (LR ; Chorley, Malm, \& Poaorzelski, 1957); $L R=H L^{2} \pi / 4 A$. (v) Hypsometric integral (HI ; simplified equation of the elevation-relief ratio proposed by Pike \& Wilson $(1971)$ was used $) ; H I=\left(H_{\text {mean }}-H_{\min }\right) /\left(H_{\max }-H_{\min }\right)$ where $H_{\text {mean }}$ is the mean height in a catchment. The lower values of $L R$ and $C C$ and the higher value of $F F$ indicate the more compact shape of the catchment and hence the lesser time of concentration for runoff and the more soil erosion (Morgan, 1996). Strahler (1952) found that a catchment at a younger evolutionary stage is highly susceptible to erosion and has a large $H I$ value, but it decreases as the landscape is denuded towards a stage of maturity and old age. The $H I$ value can be used as an estimator of erosion status of catchments (Singh, Sarangi, \& Sharma, 2008), such as the watershed is old and fully stabilized (HI [?] 0.3$)$; equilibrium or mature stage (0.3[?] $H I$ [?]0.6); and disequilibrium or young stage (HI [?] 0.6), in which the watershed is highly susceptible to erosion (Strahler 1952). Values of the parameters that used to express the geomorphic indices, such as $A$, $P e$, ground heights, $H L$, were obtained from the DEM for the 2005 orthophotograph using ArcGIS 10.1 (ESRI, Redlands) and the 2005 field survey.

Gully topographic thresholds, the relationships of the slopes at the gully heads $(s)$ that were formed before 1957, between 1957 and 1972, and between 1972 and 2005 and the upslope drainage areas of the gully heads (a) were investigated for the main gully channels of the sub-areas. Land use/cover in the 12 catchments was categorised into forest, grassland, and farmland on 1957 and 1972 aerial images and 2005 orthophotographs, and each polygon area was obtained by using ArcGIS.

\subsection{Long-term gully volume change}

Changes in both mean volume of the gully networks $(V)$ and mean area-specific volume of the gully networks $\left(V_{a}\right)$ for the two sub-areas from 1957 to 2005 were well approximated by exponential functions $\left(\mathrm{R}^{2}=0.99\right.$; 
Mukai, 2017). During the entire study period, $V$ of the gully networks in the two sub-areas were almost the same scale, whereas $V_{a}$ of the gully network in the Rift margin sub-area was always higher than that in the Valley floor sub-area, and the gap between the two sub-areas widened as time passed. The mean area-specific gully erosion rate $(A E M)$ for the 12 catchments from 1957 to 2005 was $16.2 \mathrm{Mg} \mathrm{ha}^{-1} \mathrm{y}^{-1} ; 25.1$ $\mathrm{Mg} \mathrm{ha}{ }^{-1} \mathrm{y}^{-1}$ for the Rift margin and $10.5 \mathrm{Mg} \mathrm{ha}^{-1} \mathrm{y}^{-1}$ for the Valley bottom sub-areas.

\subsection{Statistical analysis}

The geomorphic parameters $(H L, A, P e$, and $H D C)$ and indices $(C C, F F, R R, L R$, and $H I)$ of the catchments were grouped according to the Rift margin and Valley floor derivations. Normality of each geomorphic parameter and index in each group was tested with the Kolmogorov-Smirnov test $(\alpha=0.05)$ and the Shapiro-Wilk test $(\alpha=0.05)$, and homogeneity of variance was tested with the Levene test $(\alpha=$ $0.05)$. For the parameters and indices that were tested for normality and homogeneity of variance, a t-test was applied to detect differences in the mean values between the two groups; otherwise, a non-parametric test was applied.

Least square regression analysis was applied for log-transformed $s$ (slope of the gully head) and $a$ (upslope drainage area) to draw the threshold line that represented the gully topographical thresholds at each of the 12 main study gullies on a double logarithmic chart. Based on the appearance of the 12 threshold lines, hypotheses were made, and the topographical threshold of gully heads were categorised into different subgroups, e.g., periods of gully head incision or land use items around gully heads. Analysis of covariance (ANCOVA) was made to find there were significant differences $(\alpha=0.05)$ in the mean values of the dependent variable ( $s$ or $a$ ) between the different subgroups (controlled independent variable, or factor) while taking into account the influence of the uncontrolled independent variable ( $a$ or $s$ as a covariate). ANCOVA assumes that: (i) the dependent variables are normally distributed, and those variances are equal overall subpopulations; (ii) the interaction between the factor and covariate are negligible; (iii) a linear relationship between the covariate and dependent variable. In the analysis, these assumptions were tested, and post hoc tests were made using the Bonferroni correction method to find the subgroups that had significant differences in the mean values. SPSS ver. 20 (IBM) was used for the statistical analyses.

\section{RESULTS}

\subsection{Temporal and spatial dynamics of catchment geomorphic characteristics}

All values of the catchment geomorphic parameters, $H L$ (maximum catchment length), $A$ (catchment area), $P e$ (catchment perimeter), and $H D C$ (height difference between the outlet and the highest point) showed increasing tendencies as the gully networks expanded over time (Table 1). Over the three years, 1957, 1972, and 2005, no areal aspect of catchment geomorphic parameters, $H L, A$, and $P e$, showed any significant differences $(p>0.05)$ between the two sub-areas. The same was true for the catchment areal aspect indices, $L R$ (lemniscate ratio), $C C$ (compactness coefficient), and FF (form factor; Table 1). Besides, no notable increasing or decreasing tendencies in $L R, C C$, and $F F$ were observed over the three periods. The relationships between $H L$ and $A$ (Figure 3 (a)) and $P e$ and $A$ (Figure 3 (b)) showed the same spatial and temporal trends; (i) regardless of the year and sub-area, all the data appeared to be positioned on the linear lines that represented the $H L-A$ and $P e-A$ relationships; and (ii) the Valley bottom stretched the $H L-A$ and $P e$ - Alinear lines over time, i.e., the Valley bottom main gullies largely extended in terms of all of the $H L, A$, and $P e$ over time, whereas the temporal changes were limited for the Rift margin main gullies.

In contrast, the catchment relief aspect parameter $H D C$ (height difference for catchments) showed a significant difference $(p<0.01)$ between the two sub-areas (Table 1$)$. The same was true for the catchment relief aspect indices, $R R$ (relief ratio) and $H I$ (hypsometric integral). Over the three years, either $H D C$ or $R R$ values have not changed much for the Rift margin (0.38-0.40 or 0.12-0.14) or Valley bottom (0.08-0.11 or 0.05-0.06) sub-areas. However, the HDCs of the Rift margin in 1957 and 1972 were approximately 4.8 times higher than those of the Valley bottom, indicating the catchments in the Rift margin sub-area had more erosive runoff that had higher potential energy for soil erosion and, therefore, had a higher erosion risk than those in the Valley bottom sub-area since the gully incision. The $H I$ values of the Rift margin 
shifted from 0.37 in 1957 to 0.33 in 2005, indicating the catchments were always at the equilibrium or mature stage, whereas those of the Valley bottom shifted from 0.60 in 1957 and 1972 to 0.47 in 2005, indicating the catchments recently have developed from disequilibrium/young stage to equilibrium/mature stage. The relationship between $H L$ and $H D C$, which corresponds to $R R$ (Figure 3 (c)) showed a contrasting trend between the sub-areas; (i) regardless of the years, all the data appeared to be positioned on the linear lines representing the $H L-H D C$ relationships, i.e., maintaining almost the same $R R$ values, which were specific to each sub-area; and (ii) the Valley bottom main gullies largely extended in terms of both height difference $(H D C)$ and catchment length $(H L)$. In contrast, the temporal changes were limited for the Rift margin main gullies.

\subsection{Spatial and temporal dynamics of gully topographical thresholds}

All the topographical thresholds of the gully heads in the 12 main gully channels were approximated by the lines that represented power functions (Figure 4(a) for the Rift margin and Figure 4(b) for the Valley bottom); the coefficients of determination were 0.63-0.89 (the mean 0.76) for the Rift margin and 0.650.99 (the mean 0.84) for the Valley bottom. Besides the threshold lines for each main gully channel, the topographical thresholds of the gully heads categorised by gully head incision periods (before 1957, 19571972, and 1972-2005) in a sub-area can be approximated by the lines representing power functions (Figures 4(c)); the coefficients of determination were $0.82-0.88$ for the Rift margin and $0.82-0.87$ for the Valley bottom. It appeared that 2 data for the Rift margin and 3 data for the Valley bottom were outliers (rounded by solid red lines in Figures 4(a) and 4(b)). All of these gully heads were formed at lower threshold levels than those of each corresponding period. According to aerophoto-interpretation and field observations, it was evident that the formation of these gully heads was influenced by roads (cattle passageway). Nyssen et al. (2002) found that the slope gradients of the gully heads influenced by the road were lower than those without the influence of the road (not statistically significant); lowering topographic threshold levels. Thus, these outliers were excluded from the subsequent analysis.

For both the sub-areas, 3 threshold lines for before 1957, 1957-1972, and 1972-2005 appear to be parallel with one another, and as time passes, they shifted towards the origin, i.e., in equation (1), the exponent $b$ values were rather static, whereas the threshold coefficient $k$ values decreased over time. ANCOVA for the 3 subgroups of the (i) before 1957, (ii) 1957-1972, and (iii) 1972-2005 for the Rift margin found the hypothesis of no interaction between the 3 subgroups and the covariate $s$ was rejected $(\alpha=0.05)$, i.e., the 3 threshold lines cannot be paralleled with one another. However, ANCOVA for the 3 subgroups of the (iv) before 1957, (v) 1957-1972, and (vi) 1972-2005 for the Valley bottom found that all the ANCOVA-assumptions were fulfilled, indicating the 3 threshold lines can be paralleled with one another. The post hoc tests showed that there were significant difference between (i) before 1957 and (iii) 1972-2005 and between (ii) 1957-1972 and (iii) 1972-2005. Thus, the threshold lines representing gully head positions in the Valley bottom sub-area maintained almost the same exponent $b$ while the threshold coefficient $k$ decreased as time passed from before 1957, to 1957-1972, and to 1972-2005.

The threshold lines that represented the land use items (forest, grassland, and farmland) around the position of the gully head in the two sub-areas (Figure 4(d)) can be approximated by power functions; the coefficients of determination were 0.62-0.95 for the Rift margin and 0.80-0.89 for the Valley bottom. ANCOVAs both for the 3 subgroups of the (i) forest, (ii) grassland, and (iii) farmland in the Rift margin and for the 3 subgroups of the (iv) forest, (v) grassland, and (vi) farmland in the Valley bottom found that all the ANCOVA-assumptions were fulfilled, indicating the 3 threshold lines in each sub-area can be paralleled with one another. The post hoc tests showed that there were significant differences between all pairs of the land use items for both the sub-areas. Thus, the threshold lines in both the Rift margin and Valley bottom sub-areas maintained almost the same exponent $b(0.506-0.598$ for the Rift margin and $0.286-0.354$ for the Valley bottom) while the threshold coefficient $k$ significantly decreased as the land use around the gully heads shifted from forest, to grassland, and to farmland in both the sub-areas.

Examination of land use/cover items around the gully heads formed before 1957, 1957-1972, and 1972-2005 found that, in both the sub-areas, forest had the highest frequencies $(82 \%$ for the Rift margin and $60 \%$ for 
the Valley bottom) for the gully heads that began incision before 1957 (Table 2). Similarly, grassland had the highest (similarly, 100\% and 71\%) for the 1957-1972 gully heads, and farmland had the highest $(97 \%$ and 100\%) for the 1972-2005 gully heads. Thus, the high threshold levels for gully heads incised before 1957 and 1957-1972 in both sub-areas can be best explained by the relatively high resistance to erosion due to the protective vegetation cover. In both the sub-areas, land use/cover has continuously changed in the direction of reducing vegetation cover in the catchment since the initial gully incision. That induced reductions in the gully topographical threshold levels, which can significantly influence a further increase in gully erosion and gully network expansion.

\section{DISCUSSION}

In the evolutionary process of the gully network, the main gully channels of both the sub-areas expanded maintaining almost the same risk of soil erosion hazard specific to each sub-area. The difference in dynamic movements of the catchment geomorphic indices observed between the sub-areas is likely to be reflected by the gully network evolutionary processes specific to each sub-area. In the Valley floor catchments, gully incision started within the uppermost dense forests or grassland (all the main gullies except Hadaware) before 1957, and then they extended downwards to flat farmlands via steep slope hillsides and gentle slope farmlands as a fierce land use/cover changes occurred during the subsequent periods by 2005 (Figure 3 in Mukai (2017)). Because Hadaware $\left(A=6.1 \mathrm{~km}^{2}\right.$ in 2005) had the dense forests and grassland at the middle reach of the catchment before 1957, the gully heads incised there had over $1.5 \mathrm{~km}^{2}$ upslope drainage areas (three data rounded by red dot-line in Figure 4(b)). Then, from the middle reach gully channels formed before 1957, the Hadaware main gully extended to both upward and downward directions along slope. In contrast, no distinctive trend was observed in the starting points of gully incisions in the Rift margin catchments (Figure 3 in Mukai (2017)). In Figure 4(a), the gully heads incised before 1957 in the Rift margin sub-area can be categorised into two groups: one is the 8 gully heads that had narrow areas (7-67 ha) and steeper slopes $(0.4-2.2 \mathrm{~m} / \mathrm{m})$ and another is 4 gully heads that had broader catchment areas (67-376 ha) and gentle slopes (0.04-0.08 $\mathrm{m} / \mathrm{m}$; rounded by red dot-line in the Figure). The former 8 gully heads incised in forest area (blue diamond-shaped markers in Figure (d)) in the southern margin of the Tebba Gersa mountainous area or fault scarp, while the latter 4 gully heads incised in grassland area at the middle or lower reaches of the catchments. Then, from these short short-distance discontinuous gully channels formed before 1957, the main gullies extended to both upward and downward directions along slope. The positions of gully head incision before 1957 in the Rift margin sub-area can be explained by the topographical threshold of the gully head induced by the land use/cover at that time. Thus, the catchment areas $(A)$, maximum catchment length $(H L)$, and the height difference between the outlet and the highest point ( $H D C$ ) of the Rift margin sub-area showed only slight increases over the three periods.

Gómez Gutiérrez, Schnabel, \& Lavadzo (2009) determined topographical threshold equations of the gully heads in the 99.5 ha catchment over the 6 periods between 1945 and 2006, which had considerable land use/cover changes. The sequential topographical threshold equations showed that the values of the $b$ exponent (equation (1)) were more or less regular for the entire period (0.46-0.68), while the $k$ coefficients varied almost in an order of magnitude (0.02-0.15) and seem to reflect land use changes. Torri \& Poesen (2014) examined 63 reported topographical threshold equations from various parts of the world and found the exponent $b$ varied slightly with land use while the median coefficient $k$ increased from cropland to forest via grazing land/pasture. These findings were in line with the ones obtained from this study. The $b$ exponent values for the Rift margin that oscillated between 0.51 and 0.60 were similar to $\sim 0.5$ for permanent channels and Hortonian overland flow proposed by Montgomery and Dietrich (1994). The $b$ exponent values for the Valley bottom that oscillated between 0.29 and 0.35 were similar to 0.20 (Zucca et al., 2006) and low $b$ -values (0.10-0.30) observed in some areas in Mediterranean Europe, which may indicate subsurface process (Vandekerckhove et al., 2006). In the Valley bottom sub-area, Vertisols dominate over a wide area in the lower reach of the catchments, where subsurface erosion represented by soil piping due to tunnelling (Bernatek-Jakiel \& Poesen, 2018) are common.

The steeper slopes inherent in the Rift margin catchments have contributed to a higher risk of soil erosion 
hazard in the sub-area since gully incision, which is likely to affect more rapid change particularly in $V_{a}$ (area-specific gully volume of a gully network) in the Rift margin sub-area. It is because the areal aspect of the catchment geomorphic parameters had a relatively strong or strong correlation with only $V$ (volume of a gully network) over 1957, 1972, and 2005, whereas relief aspect of the catchment geomorphic parameters had a relatively strong or strong correlation with both $V$ and $V_{a}$ (Mukai, 2017). This agrees with Verstraeten \& Poesen (2001), Tamene et al. (2006) and Haregeweyn et al. (2008). A previous study stated that the rates of land use/cover changes in the catchments between the two periods significantly and relative strongly or strongly correlated with only $V$ (Mukai, 2017). Thus, the temporal changes in the areal aspect of the catchment morphology and land use/cover in the catchments can be responsible for the continuous increases in $V$ that had almost the same scale between the two sub-areas over time.

The combination of photogrammetric techniques, the $V$-Lrelation, and field measurements and interviews is probably a method that enables to assess spatial and temporal interactions between environmental changes and gully erosion/gully head positions.

\section{CONCLUSIONS}

As gully networks expand, catchment geomorphic parameters and indices change. The temporal changes in these parameters and indices are influenced by the temporal evolutionary processes of the gully networks specific to each sub-area. The temporal evolutionary process of the network depends on the positions of gully heads and discontinuous gullies formed particularly at the gully incision time. Those gully head positions were determined by the topographical threshold equations of the sub-area and land use/cover at that time because the threshold equations were a function of dominant erosion process specific to a sub-area and the topographical threshold levels significantly differed between land use/cover items.

Despite the difference observed in the gully network evolutionary process between the sub-areas, the areal aspect catchment geomorphic indices, which can have a significant impact on $V$, did not show any increasing or decreasing tendencies over time. The relief aspect catchment geomorphic indices, which can have a significant impact on $V_{a}$, also have maintained similar patterns of spatial and temporal changes; their spatial difference inherent between the sub-areas has been maintained over time. Spatial variation and temporal changes in land use/cover items can be another driving force of $V$. Since the initial gully incision, land use/cover items have changed to reduce vegetation cover continuously and to lower topographical threshold levels in both the sub-areas. Thus, the spatial variability and its temporal changes in relief aspect of the catchment morphology specific to each sub-area can be responsible for the different patterns of increases in $V_{a}$ between the sub-areas. The continuous reduction in vegetation cover induced by the changes in land use/cover over time can be the main driving force of the similar scale and changing patterns of $V$ between the sub-areas.

\section{ACKNOWLEDGEMENTS}

The authors would like to acknowledge the cooperation of Boset woreda Bureau of Agriculture and both Merko Odalega and Koka Gifawasen villagers. Part of this study was financially supported by the Ministry of Agriculture, Forestry and Fisheries, Japan. The authors declare no conflict of interest.

\section{REFERENCES}

Bernatek-Jakiel, A., \& Poesen, J. (2018). Subsurface erosion by soil piping: significance and research needs. Earth-Science Reviews 185 , 1107-1128. https://doi.org/10.1016/j.earscirev.2018.08.006

Billi, P., \& Dramis, F. (2003). Geomorphological investigation on gully erosion in the Rift Valley and the northern highlands of Ethiopia.Catena 50 , 353-368. https://doi.org/10.1016/S0341-8162(02)00131-5

Boardman, J. (2014). How old are the gullies (dongas) of the Sneeuberg uplands, Eastern Karoo, South Africa? Catena 113 , 79-85. https://doi.org/10.1016/j.catena.2013.09.012

Chandrashekar, H., Lokesh, K.V., Sameena, M., Jyothi roopa, \& Ranganna, G. (2015). GIS-based morphometric analysis of two reservoir catchments of Arkavati River, Ramanagaram District, Karnataka. Aquatic 
Procedia 4, 1345-1353. https://doi.org/10.1016/j.aqpro.2015.02.175

Chorley, R. J., Malm, D. E., \& Poaorzelski, H. A. (1957). A new standard for estimating basin shape. American Journal of Science255 , 138-141. http://www.ajsonline.org/content/255/2/138.extract

Frankl, A, Poesen, J., Haile, M., Deckers, J., \& Nyssen, J. (2013a). Quantifying longterm changes in gully networks and volumes in dryland environments: the case of Northern Ethiopia. Geomorphology 201 , 254263. https://doi.org/10.1016/j.geomorph.2013.06.025

Frankl, A., Poesen, J., Scholiers, N., Jacob, M., Haile, M., Deckers, J., \& Nyssen, J. (2013b). Factors controlling the morphology and volume (V)-length (L) relations of permanent gullies in the northern Ethiopian Highlands. Earth Surface Process and Landforms 38 , 1672-1684. https://doi.org/10.1002/esp.3405

Gomez Gutierrez, A., Schnabel, S., \& Lavado, C. F. (2009). Gully erosion, land use and topographical thresholds during the last 60 years in a small rangeland catchment in SW Spain. Land Degradation 83 Development 20 , 535-550. https://doi.org/10.1002/ldr.931

Gravelius, H. (1914). Flusskunde. Berlin: Goschen'sche Verlagshandlung.

Haregeweyn, N., Poesen, J., Nyssen, J., Govers, G., Verstraeten, G., Vente, J., ... Haile, M. (2008). Sediment yield variability in northern Ethiopia: A quantitative analysis of its controlling factors. Catena 75 , 65-76. https://doi.org/10.1016/j.catena.2008.04.011

Horton, R. E. (1932). Drainage basin characteristics. Transactions, American Geophysical Union 13 , 350361. https://doi.org/10.1029/TR013i001p00350

Katsurada, Y., Hoshino, M., Yamamoto, K., Yoshida, H., \& Sugitani, K. (2007). Gully head retreat of Awach-Kano gullies, Nyanza Province, Kenya: Field measurements and pixel-based upslope catchment assessment.African Study Monographs 28(3) , 125-141. https://doi.org/10.14989/68261

Kompani-Zare, M, Soufi, M., Hamzehzarghani, H., \& Dehghani, M. (2011). The effect of some watershed, soil characteristics and morphometric factors on the relationship between the gully volume and length in Fars Province, Iran. Catena 86 , 150-159. https://doi.org/10.1016/j.catena.2011.03.008

Li, Z., Zhang, Y., Zhu, Q., Yang, S., Li, H., \& Ma, H. (2017). A gully erosion assessment model for the Chinese Loess Plateau based on changes in gully length and area. Catena 148, 195-203. https://doi.org/10.1016/j.catena.2016.04

Martinez-Casasnovas, J. A., Ramos, M. C., \& Garcia-Hernandez, D. (2009). Effects of land-use changes in vegetation cover and sidewall erosion in a gully head of the Penedes region (northeast Spain). Earth Surf. Process. Landforms 34, 1927-1937. https://doi.org/10.1002/esp.1870

Montgomery, D. R., \& Dietrich, W. E. (1994). Landscape dissection and drainage area-slope thresholds. In M. J. Kirkby (Ed.), Process models and theoretical geomorphology (pp. 221-246): John Wiley \& Sons Ltd.

Morgan, R. P. C. (1996). Soil Erosion and Conservation. Harlow: Longman.

Mukai, S. (2017). Gully erosion rates and analysis of determining factors: a case study from the semi-arid main Ethiopian Rift Valley.Land Degradation 63 Development 28, 602-615. https://doi.org/10.1002/ldr.2532

Muňoz-Robles, C., Reid, N., Frazier, P., Tighe, M., Briggs, S. V., \& Wilson, B. (2010). Factors related to gully erosion in woody encroachment in south-eastern Australia. Catena 83 , 148-157. https://doi.org/10.1016/j.catena.2010.

Ndomba, P. M., Mtalo, F., \& Killingtveit, A. (2009). Estimating gully erosion contribution to large catchment sediment yield rate in Tanzania.Physics and Chemistry of the Earth, Parts A/B/C34(13-16) , 741-748. https://doi.org/10.1016/j.pce.2009.06.009

Nyssen, J., Poesen, J., Moeyersons, J., Luyten, E., Maude, V. P., Deckers, J., .. Govers, G. (2002). Impact of road building on gully erosion risk: a case study from the northern Ethiopian highlands. Earth Surface Processes and Landforms 27, 1267-1283. https://doi.org/10.1002/esp.404 
Nyssen, J., Poesen, J, Veyret-Picot M, Moeyersons J, Haile M, Deckers J, .. Govers G. (2006). Assessment of gully erosion rates through interviews and measurements: a case study from northern Ethiopia. Earth Surface Processes and Landforms 31 , 167-185. https://doi.org/10.1002/esp.1317

Nyssen, J., Poesen, J., Moeyersons, J., Haile, M., \& Deckers, J. (2008). Dynamics of soil erosion rates and controlling factors in the Northern Ethiopian Highlands-towards a sediment budget. Earth Surface Processes and Landforms 33 , 695-711. https://doi.org/10.1002/esp.1569

Parkner, T, Page, M. J., Marutani, T., \& Trustrum, N. A. (2006). Development and controlling factors of gullies and gully complexes, East Coast. N. Z. Earth Surface Process and Landforms 31 , 187-199. https://doi.org/10.1002/esp.1321

Pike, R. J., \& Wilson, S. E. (1971). Elevation-relief ratio, hypsometric integral and geomorphic areaaltitude analysis. Geological Society of America Bulletin 82 , 1079-1084. https://doi.org/10.1130/00167606(1971)82[1079:ERHIAG]2.0.CO;2

Poesen, J., Nachtergaele, J., Verstraeten, G., \& Valentin, C. (2003). Gully erosion and environmental change: importance and research needs. Catena 50 , 91-133. https://doi.org/10.1016/S0341-8162(02)00143-1

Schumm, S. A. (1956). Evolution of drainage system and slope in badland at Perth Amboy, New Jersey. Bulletin of Geological Society of America 67, 597-646. https://doi.org/10.1130/0016-7606(1956)67[597:EODSAS]2.0.CO;2

Singh, O., Sarangi, A., \& Sharma, M. C. (2008). Hypsometric integral estimation methods and its relevance on erosion status of north-western Lesser Himalayan watersheds. Water Resources Management 22 , 15451560. https://doi.org/10.1007/s11269-008-9242-z

Strahler, A. N. (1952). Hypsometric (area-altitude) analysis of erosional topography. Geological Society of America Bulletin63 , 1117-1142. https://doi.org/10.1130/0016-7606(1952)63[1117:HAAOET]2.0.CO;2

Tamene, L., Park, S. J., Dikau, R., \& Vlek, P. L. G. (2006). Analysis of factors determining sediment yield variability in the highlands of northern Ethiopia. Geomorphology 76, 76-91. https://doi.org/10.1016/j.geomorph.2005.10.007

Tebebu, T. Y., Abiy, A. Z., Zegeye, A. D., Dahlke, H. E., Easton, Z. M., Tilahun, S. A., ... Steenhuis, T. S. (2010). Surface and subsurface flow effect on permanent gully formation and upland erosion near Lake Tana in the northern highlands of Ethiopia. Hydrology and Earth System Sciences 14 , 2207-2217. https://www.hydrol-earth-syst-sci.net/14/2207/2010/

Torri, D., \& Poesen, J. (2014) A review of topographic threshold conditions for gully head development in different environments,Earth Science Reviews 130 , 73-85. https://doi.org/10.1016/j.earscirev.2013.12.006

Valentin, C., Poesen, J., \& Li, Y. (2005). Gully erosion: impacts, factors and control. Catena 63 , 132-153. https://doi.org/10.1016/j.catena.2005.06.001

Vandekerckhove, L., Poesen, J., Oostwoud Wijdenes, D., Gyssels, G., Beuselinck, L., \& de Luna, E. (2000). Characteristics and controlling factors of bank gullies in two semi-arid mediterranean environments. Geomorphology 33 , 37-58. https://doi.org/10.1016/S0169-555X(99)00109-9

Verstraeten, G., \& Poesen, J. (2001). Factors controlling sediment yield from small intensity cultivated catchments in a temperate humid climate. Geomorphology 40 , 123-144. https://doi.org/10.1016/S0169$555 \mathrm{X}(01) 00040-\mathrm{X}$

Yibeltal, M., Tsunekawa, A., Haregeweyn, N., Adgo, E., Meshesha, D. T., Aklog, D., ... Ebabu, K. (2019). Analysis of long-term gully dynamics in different agro-ecology settings. Catena, 179 , 160-174. https://doi.org/10.1016/j.catena.2019.04.013

Zegeye, A. D., Langendoen, E. J., Stoof, C. R., Tilahun, S. A., Dagnew, D. C., Zimale, F. A., .... Steenhuis, T. S. (2016). Morphological dynamics of gully systems in the subhumid Ethiopian Highlands: The Debre Mawi watershed. Soil 2 , 443-458. https://www.soil-journal.net/2/443/2016/ 
Zucca, C., Canu, A., \& Della Peruta, R. (2006). Effects of land use and landscape on spatial distribution and morphological features of gullies in an agropastoral area in Sardinia (Italy). Catena 68: 87-95. https://doi.org/10.1016/j.catena.2006.03.015

TABLE 1 Catchment geomorphic parameters and indices in 1957, 1972, and 2005

\begin{tabular}{|c|c|c|c|c|c|}
\hline Study catchments & 2005 & 2005 & 2005 & 2005 & 2005 \\
\hline & $A$ & $H L$ & $P e$ & $L R$ & $C C$ \\
\hline Boruamba & 3.5 & 4.2 & 9.8 & 4.0 & 1.5 \\
\hline Telilo & 2.6 & 4.2 & 8.3 & 5.3 & 1.5 \\
\hline Adare & 1.2 & 3.4 & 6.8 & 7.8 & 1.8 \\
\hline Gebruamba & 2.8 & 4.1 & 8.1 & 4.7 & 1.4 \\
\hline Koka & 0.8 & 2.5 & 4.9 & 5.7 & 1.5 \\
\hline Hadaware & 6.1 & 6.2 & 15.6 & 4.9 & 1.8 \\
\hline Abharo & 4.3 & 6.0 & 10.0 & 6.5 & 1.4 \\
\hline Kawa Adami & 1.2 & 3.3 & 6.6 & 7.3 & 1.7 \\
\hline Aware & 5.9 & 7.5 & 15.0 & 7.4 & 1.7 \\
\hline Odalega & 4.0 & 5.8 & 11.6 & 6.6 & 1.6 \\
\hline Merko & 0.1 & 0.6 & 3.2 & 3.6 & 3.4 \\
\hline Goro & 0.1 & 0.7 & 1.6 & 4.3 & 1.5 \\
\hline Rift margin Valley bottom $P$-value Mean & 2.23 .1 ns 2.7 & 3.74 .3 ns 4.0 & 7.69 .1 ns 8.5 & 5.55 .8 ns 5.7 & 1.51 .9 ns 1.7 \\
\hline \multirow[t]{2}{*}{ Study catchments } & 1957 & 1957 & 1957 & 1957 & 1957 \\
\hline & $A$ & $H L$ & $P e$ & $L R$ & $C C$ \\
\hline Boruamba & 3.5 & 4.2 & 9.8 & 4.0 & 1.5 \\
\hline Telilo & 0.9 & 2.9 & 5.9 & 7.7 & 1.8 \\
\hline Adare & 0.7 & 2.6 & 5.2 & 7.2 & 1.7 \\
\hline Gebruamba & 2.8 & 4.1 & 8.1 & 4.7 & 1.4 \\
\hline Koka & 0.8 & 2.5 & 4.9 & 5.7 & 1.5 \\
\hline Hadaware & 3.4 & 4.6 & 9.3 & 5.0 & 1.4 \\
\hline Abharo & 1.0 & 2.5 & 5.0 & 5.0 & 1.4 \\
\hline Kawa Adami & 0.1 & 0.7 & 1.3 & 3.2 & 1.1 \\
\hline Aware & 1.7 & 3.0 & 6.0 & 4.2 & 1.3 \\
\hline Odalega & 0.2 & 1.1 & 2.2 & 4.4 & 1.3 \\
\hline Merko & 0.1 & 0.5 & 1.2 & 3.0 & 3.0 \\
\hline Goro & 0.1 & 0.7 & 1.6 & 4.3 & 4.3 \\
\hline Rift margin Valley bottom $P$-value Mean & 1.80 .9 ns 1.3 & 3.31 .9 ns 2.4 & 6.83 .8 ns 5.0 & 5.84 .2 ns 4.9 & 5.84 .2 ns 4.9 \\
\hline
\end{tabular}

Catchment area $\left(A ; \mathrm{km}^{2}\right)$; maximum catchment length $(H L ; \mathrm{km})$; catchment perimeter $(P e ; \mathrm{km})$; lemniscate ratio $(L R)$; compactness coefficient $(C C)$; form factor $(F F)$; height difference between the outlet and the highest point $(H D C ; \mathrm{km})$; relief ratio $(R R)$; hypsometric integral $(H I)$. ns , not significant; ${ }^{* *} P$ $<0.01$

TABLE 2 Land use/cover around the gully heads in 1957, 1972, and 2005

\begin{tabular}{lllllll}
\hline Gully head incision period & $n$ & 1957 & 1957 & 1957 & 1972 & 1972 \\
\hline & & Forest & Grassland & Farmland & Forest & Grassland \\
Rift margin & Rift margin & Rift margin & Rift margin & Rift margin & Rift margin & Rift marg \\
Before 1957 & 17 & $14(82)$ & $3(18)$ & $0(0)$ & &
\end{tabular}




\begin{tabular}{lllllll}
\hline Gully head incision period & $n$ & 1957 & 1957 & 1957 & 1972 & 1972 \\
\hline $1957-1972$ & 6 & & & & $0(0)$ & $6(100)$ \\
$1972-2005$ & 34 & & & & \\
Valley bottom & Valley bottom & Valley bottom & Valley bottom & Valley bottom & Valley bottom & Valley bo \\
Before 1957 & 15 & $9(60)$ & $6(40)$ & $0(0)$ & & $10(71)$ \\
$1957-1972$ & 14 & & & & $10(71)$ \\
$1972-2005$ & 7 & & & &
\end{tabular}

The numbers are frequencies followed by percentages in brackets

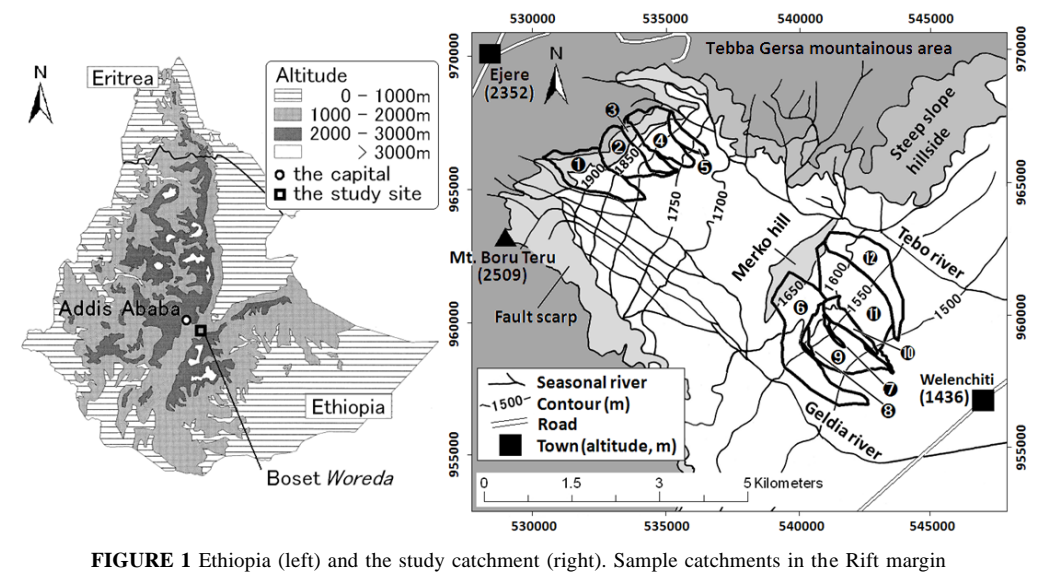

sub-area (1. Boruamba; 2. Telilo; 3. Adare; 4. Gebruamba; and 5. Koka) and Valley floor sub-area

(6. Hadaware; 7. Merko; 8. Goro; 9. Abharo; 10. Kawa adami; 11. Aware; and 12. Odalega) 

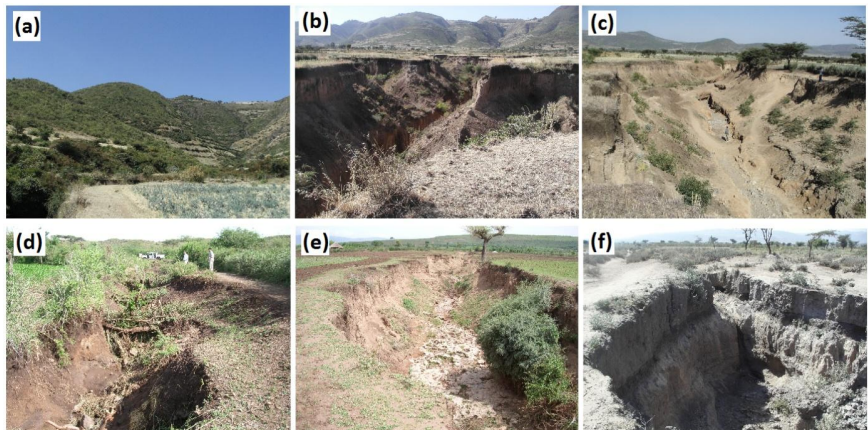

FIGURE 2 Examples of gully cross-sections in the rift margin ((a), (b), and (c)) and the valley bottom ((d), (e), and (f)) sub-areas. All photos were taken in 2005 or 2006. (a) The southeastern cliff of the Rift margin plateau, which is located in the most upper reaches of the Rift margin gullies, (b) Boruamba main gully channel $0.7 \mathrm{~km}$ downward from the foot of the southeastern cliff (10.9 m top width and $10.3 \mathrm{~m}$ depth), (c) $2.3 \mathrm{~km}$ downward from (b) (12.5 m top width and $9.2 \mathrm{~m}$ depth), (d) Abharo main gully channel $0.3 \mathrm{~km}$ downward from the southern foot of Merko hill (4.7 $\mathrm{m}$ top width and $2.8 \mathrm{~m}$ depth), (e) $1.2 \mathrm{~km}$ far from (d) (9.6 m top width and $5.6 \mathrm{~m}$ depth), (f) $3.7 \mathrm{~km}$ far from (e) (8.1 m top width and $4.6 \mathrm{~m}$ depth) 

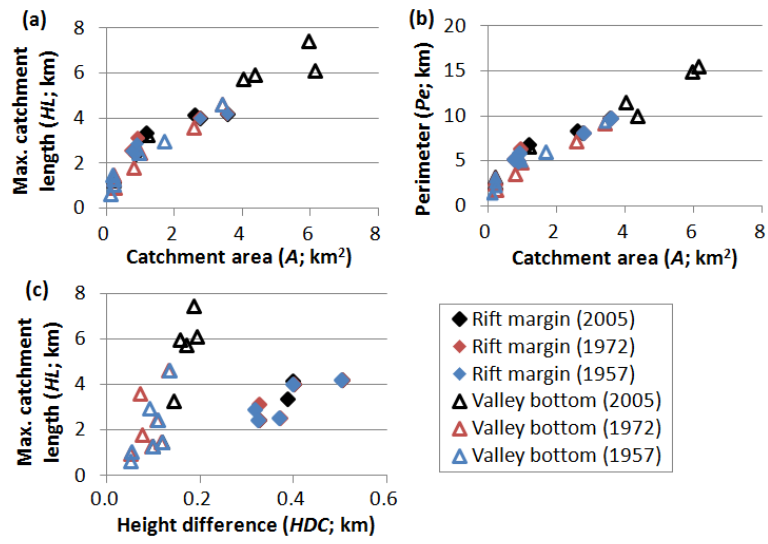

- Rift margin (2005)

- Rift margin (1972)

Rift margin (1957)

$\Delta$ Valley bottom (2005)

$\Delta$ Valley bottom (1972)

$\Delta$ Valley bottom (1957)

FIGURE 3 Spatial and temporal dynamics in the relationships between catchment geomorphic parameters over 1957, 1972, and 2005 for 5 catchments in the Rift margin sub-area and 7 catchments in the Valley bottom sub-area: (a) the maximum catchment length $(H L)$ and catchment area $(A)$; (b) the catchment perimeter $(P e)$ and catchment area $(A)$; and (c) the maximum catchment length $(H L)$ and height difference for the catchment $(H D C)$ 

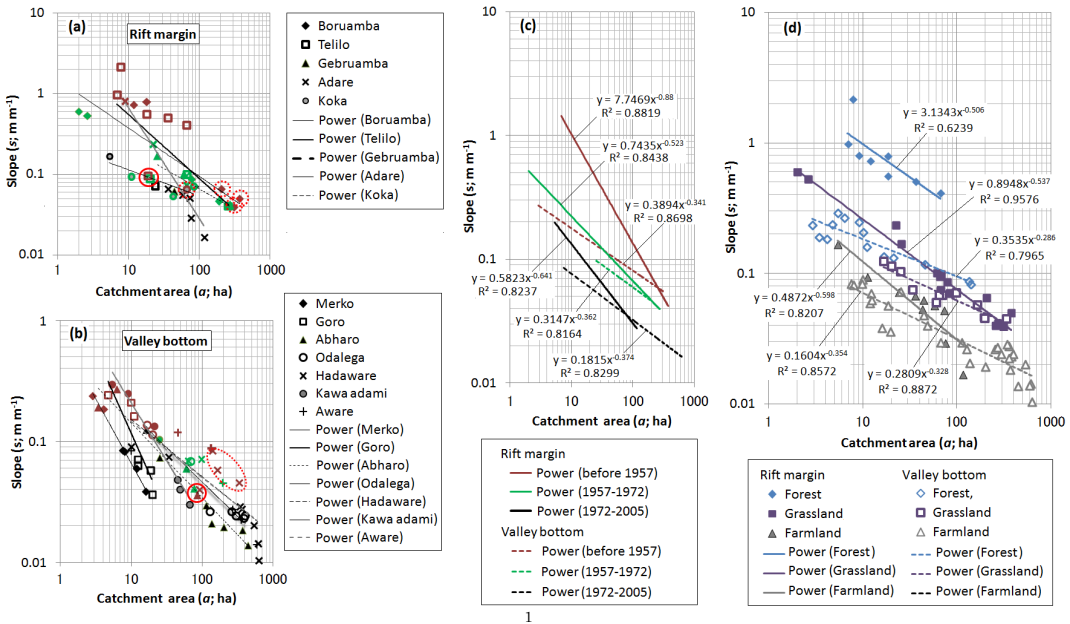